Diterbitkan oleh Pusat Studi Gender dan Anak LP2M IAIN Syekh Nurjati Cirebon, Indonesia

\title{
PENERAPAN KONSEP PENDIDIKAN LUKMANUL HAKIM DALAM KELUARGA
}

\section{Elfan Fanhas Fatwa Khomaeny* Universitas Muhammadiyah Tasikmalaya}

Elfan.fanhas@umtas.ac.id

\section{- Received: 22 Nov 2019 •Accepted: 07 Des 2019 •Published online: 11 Des 2019}

\begin{abstract}
Parenting and education for early childhood, in the era of Industrial 4.0 and the era of Society 5.0, can not be done with conventional and classical approaches, because in this era occurs a rapid industrial revolution (speed), change suddenly, Unfriendly with slowly, and unpredictable, which produces many sophisticated industrial products, and also affects the social change drastically. This research uses an explanation method based on library research, with the following steps: Identifying, reviewing, studying, analyzing, and syntactic the implementation of the family education concept Based on Q.S. Lukman (31): 12-19. Family education concepts based on Lukmanul Hakim that can be applied are as follows: (1). Introducing the creator (2). Introducing the origin of humans and their own (3). Teaching science as the basis of argumentation, (4). Introducing the law of causality, (5). Training and making habitual to prayer, (6). Training and making habitual to amar ma'ruf nahi munkar, (7). Training the patience, (8). Training to caring for others, (9). Training the children not to be arrogant or humble (10). Training the children live modestly, (11). Training children for good manners or politeness. The methods and models used are adapted to the material to be delivered.
\end{abstract}

Keywords: Education Concept, Lukmanul Hakim, Family

Abstrak: Pengasuhan dan pendidikan anak di era Industri 4.0 dan Era Society 5.0 tidak dapat dilakukan dengan pendekatan konvensional dan klasikal, karena pada era ini terjadi sebuah revolusi industri yang sangat cepat (speed), berubah mendadak (suddent change), tidak bersahabat dengan yang lambat (unfriendly with slowly), masa depan yang susah untuk diprediksi (unpredictable), yang menghasilkan banyak produk hasil industri yang canggih (sophisticated) dan berdampak pula pada perubahan sosial masyarakat yang drastis. Penelitian ini menggunakan metode eksplanatif didasarkan pada studi pustaka (library Research), dengan langkah-langkah sebagai berikut : Mengidentifikasi, Mengkaji, Mendalami, Menganalisis dan sintaksis penerapan konsep pendidikan Lukmanul Hakim berdasarkan pada Q.S. Lukman (31):12-19 pada keluarga. Konsep pendidikan Lukmanul Hakim yang dapat diterapkan dalam keluarga, adalah sebagai berikut: (1) Mengenalkan pengetahuan tentang sang pencipta; (2) Mengenalkan pengetahuan tentang diri dan asal usul manusia; (3) Mengajarkan ilmu pengetahuan sebagai landasan argumentasi dalam menjalani kehidupan; (4) Mengenalkan dan mengajarkan kepada anak pengetahuan tentang hukum sebab akibat (hukum kausalitas); (5) Melatih dan membiasakan sholat; (6) Melatih dan membiasakan beramar maruf nahi munkar; (7) Melatih dan membiasakan anak untuk bersabar; (8) Melatih dan membiasakan anak untuk memiliki kepedulian kepada sesama; (9) Melatih

\footnotetext{
* Corresponding Elfan Fanhas Fatwa Khomaeny, Email: Elfan.fanhas@umtas.ac.id
} 
dan membiasakan anak untuk tidak memiliki sifat sombong dan angkuh; (10) Melatih dan membiasakan anak untuk hidup bersahaja; (11) Melatih dan membiasakan anak untuk memiliki sopan santun. Adapun metode dan model yang digunakan disesuaikan dengan materi yang akan disampaikan.

Kata Kunci: Konsep Pendidikan, Lukmanul Hakim, Keluarga

\section{A. PEndahuluan}

Pengasuhan dan pendidikan anak di era Industri 4.0 dan Era Society 5.0 tidak dapat dilakukan dengan pendekatan konvensional dan klasikal, karena pada era ini terjadi sebuah revolusi industri yang sangat cepat (speed), berubah mendadak (suddent change), tidak bersahabat dengan yang lambat (unfriendly with slowly), masa depan yang susah untuk diprediksi (unpredictable), yang menghasilkan banyak produk hasil industri yang canggih (sophisticated) bahkan melampaui kesiapan sumber daya manusia secara akumulatif dalam mengantisipasi dampakdampak yang terjadi dan akan terjadi.

Menurut Chandrawaty dan Elfan Fanhas Fatwa Khomaeny (2019:103-105), bahwa Era Industri 4.0 dan Era Society 5.0 akan memunculkan dampak positif dan negatif, dampak positif yang diprediksikan akan muncul, diantaranya: 1). Kemudahan mengakses informasi dan pengetahuan dari berbagai belahan dunia dengan kecanggihan internet secara real time on time; 2). Interaksi dan sosialisasi di dunia maya, tidak dibatasi ruang dan waktu; 3). kehidupan manusia akan sangat dimudahkan dan diringankan dengan bantuan kecanggihan teknologi robot berbasis artificial intelligences; 4). Kebutuhan manusia menjadi simpel dan praktis dengan sistem serba digital; batas negara dan kawasan menjadi semu atau hanya ada dalam peta belaka, tetapi tidak dalam aktivitas keseharian manusia, karena manusia dengan bebas dan mudah untuk masuk dan keluar dari satu negara ke negara lainnya; 5). Pelayanan publik maupun private menjadi simpel, cepat dan praktis, sehingga the excellent service menjadi alat ukur kompetisi; 6). adanya pemerataan informasi dan wawasan di seluruh pelosok wilayah, sehingga memberikan tantangan dan peluang yang sama antara penduduk yang tinggal di kota dengan yang di desa, di pesisir, maupun di pedalaman, dan dampak positif lainnya.

Sedangkan dampak negatif bagi kehidupan manusia, diantaranya : 1). Kecanggihan dan kepraktisan hidup, mendorong manusia untuk bersikap egois dan individualis; 2). Hukum rimba akan menjadi hukum yang berlaku, dimana yang kuat itulah yang berkuasa, dan yang lemah dikuasai dan ditindas; 3). Ketergantungan manusia pada internet dan alat pendukungnya sangat tinggi; 4). Tingkat stres dan 


\section{Elfan Fanhas Fatwa Khomaeny}

kecanduan teknologi meningkat drastis; 5). Norma dan nilai agama atau susila dalam kehidupan manusia melemah; 6). Kemampuan untuk bersosialisasi secara langsung menjadi rendah; 7). Ancaman kerentanan fisik manusia; 8). Sosial emosional masyarakat menjadi rendah dan rentan terhadap konflik dan konfrontasi; 9). Memunculkan ketidakteraturan kehidupan manusia dan semua menjadi sulit untuk diprediksi; 10). Hilangnya keanekaragaman bahasa dan budaya, karena yang ada adalah bahasa dan budaya internasional, sedangkan budaya lokal akan tergerus dan terdegradasi secara perlahan, dan dampak negatif lainnya.

Hal tersebut di atas, akan berdampak pula pada kehidupan sosial masyarakat dewasa ini (Jenny S Radesky, Sarah E Domoff : 2019). Perubahan Sosial, Budaya, dan Teknologi (Margaret Nelson, 2010) akan berdampak pada upaya orang tua dalam mengantisipasi dan melakukan pencegahan sejak awal (early prevention) terhadap proyeksi dampak-dampak yang akan timbul. Penggunaan media digital telah mempengaruhi tumbuh kembang anak, dan orang tua dalam pengasuhannya cendrung mengalami kecemasan terhadap penggunaan media yang berlebihan tersebut. Masalah pengetahuan dan kompetensi anak secara akademik, yang dahulu menjadi faktor utama kecemasan orang tua, kini telah bergeser kepada kecemasan pada aspek tumbuh kembang anak, yang meliputi : perkembangan sosial emosional, fisik motorik, serta moral dan agama.

Perasaan khawatir dan kecemasan orang tua (parental anxiety) akan masa depan anak-anaknya sebagai reaksi atas perubahan sosial, ekonomi, dan teknologi telah mendorong orang tua untuk mencurahkan seluruh energi intelektual dan emosional, untuk menemukan sebuah konsep pengasuhan yang tepat dan atau lembaga pendidikan yang dapat memberikan pengasuhan dan pendidikan yang terbaik bagi anak-anaknya (Maia Cucchiara:2013).

Pengasuhan dan pendidikan anak yang bagaimanakah yang dapat mengatasi kecemasan orang tua?. Pertanyaan tersebut menjadi pertanyaan besar dan utama dalam fikiran orang tua masa kini, dan menjadi topik utama perbincangan orang tua baru dalam menjalani kehidupan rumah tangga pasca dianugerahi seorang anak. Banyak para ahli tumbuh kembang anak, ahli pendidikan, ahli psikologi, dan ahli terkait lainnya, mencurahkan segala upaya untuk melakukan penelitian, sehingga dapat menemukan sebuah konsep pengasuhan dan pendidikan yang tepat bagi anak di era Industri 4.0 dan era society 5.0. 
Sebuah konsep haruslah mendasar dan bersifat filosofis, untuk dapat dijadikan dasar dan rujukan pengembangan secara praktik dan operasional. Bagi saya sebuah konsep yang mendasar dan filosofis haruslah didasarkan pada pengetahuan ilahiyyah berupa wahyu (divine knowladge) dan pengetahuan hasil kreasi, inovasi, dan modifikasi manusia terhadap alam semesta, isi, dan fenomena-fenomenanya (human knowladge), dan kedua hal ini saling terkait dan tidak dapat dipisahkan satu dengan lainnya seperti dua sisi mata uang, yang akan memiliki nilai dan dampak ketika dua sisi tersebut ada.

Pada artikel ini, saya akan berusaha memberikan sebuah penjelasan secara mendalam (ekspalanatif) tentang konsep pendidikan yang berdasarkan wahyu illahi, yaitu konsep pendidikan Lukmanul Hakim yang digali dan dikaji dari Q.S. Lukman (31):12-19 dikaitkan dengan upaya penerapannya di dalam pengasuhan dan pendidikan keluarga (orang tua dan orang-orang terdekat), yang disertai dengan contoh-contoh untuk mempermudah pemahaman konsep tersebut, sehingga saya berharap artikel ini dapat menjadi salah satu rujukan alternatif dan solutif bagi keluarga muslim khususnya, dalam mengasuh dan mendidik anak-anaknya di era Industri 4.0 dan era society 5.0.

Artikel ini memberikan penjelasan mendalam tentang penerapan konsep pendidikan Lukmanul Hakim dalam keluarga, berbeda dengan artikel-artikel lain yang ada, yang hanya mendeskripsikan secara sekilas tentang konsep pendidikan Lukmanul Hakim tanpa danya penjelasan yang mendetail, sehingga orang tua tidak dapat mengetahui bagaimana menerapkan konsep tersebut secara praktis dalam mengasuh dan mendidik anaknya.

Abdullah Katutu dan Abur Hamdi Usman (2015) menyatakan, bahwa tujuan dari konsep pendidikan Lukmanul Hakim adalah: tentang keimanan, hukum Islam dan moral, keselarasan antara iman, Islam dan Ihsan, secara simbolis menggambarkan hubungan manusia dengan Allah dan sesamanya, menunjukkan kewajiban kepada Allah, orang tua, diri sendiri dan orang lain, pengajaran tata krama yang baik, etika dan kesopanan atau ta'dib. Seluruh pesan Lukman meliputi ruang lingkup pendidikan secara global yang meliputi itikad baik, religius, sosial, serta pendidikan intelektual dan fisik. Puji Asmaul Chusna.(2018) membuat kesimpulan bahwa metode pendidikan menurut Lukmanul Hakim, adalah: Metode kisah; Metode nasihat; Metode Targhib dan Tarhib; Metode Keteladanan; dan Metode Pembiasaan. 
Subhan (2018) membuat kesimpulan bahwa metode pendidikan anak yang terkandung dalam Al-Quran surat Luqman ayat 13-19 adalah: Materi pendidikannya mencakup pendidikan Aqidah, pendidikan Syari"ah, dan pendidikan Akhlak; Metode pengajarannya dengan mauidloh dan tanya jawab; serta Sifat pendidik mencakup bijaksana dan kasih sayang terhadap anak didik. Latifatul Masruroh (2015), menyatakan bahwa metode pendidikan yang ada pada surat Luqman ayat 12-19 ini, terdapat sembilan metode pendidikan yang disampaikan oleh Luqman, yaitu: keteladanan, perintah dan larangan yang disertai dengan penjelasan, reward, punishment, cerita, nasehat yang menyentuh hati dan diawali dengan panggilan sayang. Sedangkan bagi Purwatiningsih, Fachrur Razi Amir, Muhammad Khoiruddin (2016) metode pendidikan anak dalam keluarga menurut al-Qur`an, di antaranya; metode wasiat, metode teladanan, metode nasihat, metode kasih sayang, metode perumpamaan dan metode ketegasan.

\section{B. METODE PENELITIAN}

Dalam melakukan penelitian ini, saya menggunakan metode eksplanatif yaitu melakukan pengkajian secara mendalam terhadap sebuah teori atau temuan berkaitan dengan penerapan konsep pendidikan Lukmanul Hakim dalam keluarga, kemudian dideskripsikan dengan pendekatan deduktif yang disertai dengan contohcontoh penerapannya. Penelitian ini dilakukan didasarkan pada studi pustaka (library Research), dengan langkah-langkah sebagai berikut :

1. Mengidentifikasi konsep pendidikan Lukmanul Hakim berdasarkan pada Q.S. Lukman (31):12-19

2. Mengidentifikasi metode pendidikan Lukmanul Hakim berdasarkan pada Q.S. Lukman (31):12-19

3. Mengkaji dan mendalami konsep dan metode pendidikan Lukmanul Hakim berdasarkan pada Q.S. Lukman (31):12-19

4. Melakukan analisis dan sintaksis penerapan konsep pendidikan Lukmanul Hakim berdasarkan pada Q.S. Lukman (31):12-19 pada keluarga

\section{HASIL DAN PEMBAHASAN}

\section{Konsep dan Metode Pendidikan Lukmanul Hakim}

Berdasarkan hasil penelitian saya terdahulu, bahwa konsep pendidikan Lukmanul Hakim dalam keluarga berdasarkan pemahaman terhadap Q.S. Lukman (31):12-19, adalah sebagai berikut: (1) Mengenalkan pengetahuan tentang sang 
pencipta; (2) Mengenalkan pengetahuan tentang diri dan asal usul manusia; (3) Mengajarkan ilmu pengetahuan sebagai landasan argumentasi dalam menjalani kehidupan; (4) Mengenalkan dan mengajarkan kepada anak pengetahuan tentang hukum sebab akibat (hukum kausalitas); (5) Melatih dan membiasakan sholat; (6) Melatih dan membiasakan beramar maruf nahi munkar; (7) Melatih dan membiasakan anak untuk bersabar; (8) Melatih dan membiasakan anak untuk memiliki kepedulian kepada sesama; (9) Melatih dan membiasakan anak untuk tidak memiliki sifat sombong dan angkuh; (10) Melatih dan membiasakan anak untuk hidup bersahaja; (11) Melatih dan membiasakan anak untuk memiliki sopan santun.

Sebelas konsep pendidikan Lukmanul Hakim tersebut, apabila dibandingkan dan diklasifikasikan dengan teori taxonomy Bloom, maka konsep pendidikan pada point 1 sampai 4 berada pada ranah aspek kognitif, apabila dipersentasekan adalah $36,36 \%$, point 5 sampai 6 berada pada ranah aspek psikomotor, apabila dipersentasekan adalah 18,18\%, sedangkan point 7 sampai 11 berada pada ranah aspek apektif, apabila dipersentasekan adalah 45,46\%. Pengembangan secara optimal seluruh aspek tumbuh kembang anak adalah sebuah keniscayaan yang harus dilakukan oleh orang tua, sehingga terjadi keselarasan antara perkembangan kognitif, psikomotor, dan apektif. Keselarasan pada tiga aspek tersebut akan membekali dan memudahkan anak dalam menghadapi persaingan di masa depannya.

Pemaparan dalam World Economic Forum dengan tema The Future of Jobs Report (2018), menyatakan bahwa skill sumber daya manusia yang dibutuhkan secara berurutan adalah sebagai berikut : 1). Complex Problem Solving; 2). Social Skill; 3). Process Skill, yaitu kemampuan yang terdiri dari: active listening, logical thinking, dan monitoring self and the others; 4). System Skill; 5). Cognitive Abilities Skill, yaitu yang terdiri dari: Cognitive Flexibility, Creativity, Logical Reasoning, Problem Sensitivity, Mathematical Reasoning, dan Visualization. Dan skill lainnya yang secara berurutan: Resource management skill, Technical skill, Content skill, dan Fisical abilities. Oleh karena itu perkembangan optimal pada seluruh aspek tumbuh kembang anak harus menjadi prioritas utama bagi orang tua dalam mempersiapkan masa depan anak-anaknya, serta kurang tepat hanya mengembangkan pada satu atu dua aspek perkembangan saja, karena hal itu akan menjadi titik lemah dan sumber masalah dalam memenangkan kompetisi masa depan. 
Dalam konsep ajaran Islam dikenal dengan istilah iman, sebagai dasar utama keberagamaan seseorang, dimana qoblun (akal dan hati), lisanun (perkataan), dan arkanun (perbuatan) memiliki keselarasan dan harmoni dalam menyakini akan kekuasaan, keagungan, dan kebesaran Sang Pencipta. Iman seseorang tidak akan pernah mencapai kesempurnaannya, apabila tidak mampu mengembangkan seluruh aspek tumbuh kembang dan menselaraskannya menjadi sebuah sistem dan gerakan yang harmoni, yang satu dengan yang lainnya terkait dan tidak dapat dipisahkan. Sebagai contoh: bagaimana seseorang dapat melakukan ibadah sholat yang baik dan benar sesuai tuntunan rasulullah s.a.w., apabila tiga aspek perkembangan itu berkembang optimal, bukankah dalam sholat pada aspek kognitif, dituntut untuk memiliki kemampuan untuk menghapal, mengerti, mengetahui, dan memahami tata cara sholat, kemudian pada aspek psikomotor seseorang dituntut untuk mampu melakukan berbagai bentuk gerakan sholat, begitu pula pada aspek apektif bahwa dalam sholat manusia dituntut untuk memiliki kekhusuan, tertib, tuma`ninah, tartil, penyerahan dan ketundukan, dan sikap-sikap lainnya.

Al-Qur’an sebagai pedoman hidup umat Islam, selain mengajarkan secara umum tentang moral ideal konsep pendidikan, juga mengajarkan secara umum tentang metode atau model pembelajaran yang dapat digunakan dalam mentransformasikan pengetahuan (transfer of knowladge) dan mentransformasikan nilai (transfer of value), yang kemudian konsep dan metode tersebut harus dikembangan oleh manusia secara berkelanjutan (continuous development) disesuaikan dengan situasi dan kondisi. Pada prinsipnya metode adalah sebuah cara yang tidak kaku tetapi fleksibel, untuk dapat menyampaikan sesuatu yang substantif dan prinsipal.

Metode pendidikan dan pembelajaran yang dapat digunakan oleh orang tua dalam mengasuh dan mendidik anaknya, yang digali dan difahami dari al-Qur’an, sebagaimana diungkapkan oleh Elfan Fanhas Fatwa Khomaeny dan Nur Hamzah (2019:72), diantaranya adalah : metode perumpamaan, metode klasikal atau nasihat, pembiasaan, perintah dan larangan, penghargaan (targhib) dan hukuman (tarhib), metode berkisah/ bercerita, metode bercakap-cakap atau dialog, metode keteladanan,metode demonstrasi dan eksperiment, metode kelompok, metode akuisisi, dan masih banyak metode lainnya yang dapat digali dan dikembangkan. 


\section{Penerapan Konsep dan Metode Pendidikan Lukmanul Hakim dalam Keluarga}

\section{Mengenalkan Pengetahuan tentang Sang Pencipta.}

Manusia sebagai makhluk harus selalu terhubung dan tergantung kepada Sang Khalik, karena manusia sebagai makhluk lemah yang tidak dapat berbuat apapun kecuali dengan bantuanNya. Manusia hidup di muka bumi ini memiliki tujuan, tugas dan fungsi yang melekat secara otomatis pada setiap diri manusia. Tujuan hidup manusia adalah mencari dan menggapai keridhaan Sang Khalik, serta menghindari kemurkaanNya. Hal ini dapat terwujud apabila manusia dapat mengetahui dan memahami siapa Sang Pencipta? Apa perintah dan laranganNya? Dan bagaimana semestinya manusia sebagai makhluk harus berprilaku kepada Sang Khalik?.

Manusia dilahirkan dari perut ibunya ke muka bumi dalam keadaan tidak mengetahui apapun, tetapi untuk menjalani kehidupan di dunia, Sang Khalik membekali dan menganugerahi manusia alat belajar yaitu: pendengaran (as-sam `a), penglihatan (al-abshar), akal fikiran dan hati nurani (fuadah). Di satu sisi bahwa manusia terlahir dalam keadaan suci (as a blank tablet), yang siap diberi titik dan kumpulan titik yang menjadi coretan kehidupannya, oleh orang terdekat dan lingkungannya, sehingga gambaran dan lukisan anak secara dominan tergantung pada lingkungan, dalam hal ini adalah orang tua yang merupakan orang atau lingkungan terdekat dengan anak. Sebagaimana hadits dari Abu Hurairah sesungguhnya dia berkata, "Rasulullah s.a.w bersabda: "tidak ada seorang anak yang terlahir melainkan ia dilahirkan dalam keadaan fitrah, maka kedua orang tuanyalah yang membuatnya menjadi Yahudi, Nasrani, maupun Majusi, sebagaimana binatang ternak melahirkan binatang ternak yang tanpa cacat. Apakah kalian merasa bahwa pada binatang ternak itu akan ada yang terpotong telinganya (misalnya)?" Kemudian Abu Hurairah berkata: "Jika kalian menghendaki, bacalah firman Allah: "(Tetaplah atas) fitrah Allah yang telah menciptakan manusia menurut fitrah itu. Tidak ada perubahan pada fitrah Allah.” (Abi al-Husaini Muslim: 1998).

Stimulasi perkembangan agama dan moral atau dikenal juga dengan istilah perkembangan spiritual harus dilakukan sejak dini, karena spiritualitas adalah keinginan yang mendalam di dalam setiap manusia untuk memberi makna. Perasaan atau pengalaman ini muncul dari waktu ke waktu. Mulai saat lahir, perkembangan spiritual melibatkan perubahan dan terus berkembang di setiap tahap pertumbuhan (Kathleen 2014, 13). Stimulasi pertama dan utama dalam perkembangan agama dan moral yang harus dilakukan orang tua kepada anaknya, 


\section{Elfan Fanhas Fatwa Khomaeny}

adalah upaya mengenalkan pengetahuan dan pemahaman tentang Sang pencipta, sehingga muncul rasa takjub yang bermuara pada perasaan cinta kepada Ilahi Rabbi yang dibuktikan dengan ketundukan dan kepatuhan yang didasari oleh keyakinan yang menyeluruh (al-yaqiinu kulluhu).

Mengenalkan sang Khalik kepada anak harus memperhatikan dan menyesuaikan dengan aspek perkembangan anak, adapun materi yang dapat dikenalkan meliputi : Sifat wajib Allah (as-Sifat al wajibah), nama-nama baik Allah (Asmaul husna), kebersamaan Allah (Maiyatullah), dan Cerita orang-orang yang di ridhai dan dimurkai Allah, serta melihat, memahami, dan memikirkan ciptaanciptaannya baik yang tersebar diseluruh penjuru alam semesta, maupun apa yang ada pada diri manusia. Metode yang dapat digunakan orang tua dalam mengenalkan Sang pencipta, diantaranya: metode menyatakan/ ikrar, bercakap-cakap, bernyanyi, tayangan film animasi, berdoa, keteladanan, karyawisata, bermain peran, demonstrasi, dan bercerita.

Contoh-contohnya sebagai berikut : dengan metode menyatakan/ ikrar yang baik dilakukan di pagi hari, dalam hal ini anak mengikrarkan sebuah ikrar janji yang isinya diantaranya adalah janji untuk menjadi hamba Allah yang baik dan menjadikan Allah di atas segalanya, dan ini dilakukan secara rutin dengan tujuan untuk menanamkan dalam benak dan otak anak tentang keesaan Allah sebagai sang pencipta. Bentuk Ikrar berisi tentang janji anak untuk mengesakan Allah yang memiliki sifat dan nama baik, misalkan:

\section{IKRAR DI PAGI HARI}

Dengan menyebut nama Allah yang maha pengasih, lagi maha penyayang Aku bersaksi bahwa Allah adalah Rabbku, dan Nabi Muhammad adalah Nabi dan Rasul Allah.

Hari ini Aku berjanji untuk bahagia, bermain bersama, berbagi dan bekerjasama.

Bernyanyi dapat juga dijadikan metode mengenalkan sifat dan nama baik Allah, karena menyanyi adalah salah satu metode yang paling disukai anak, terlebih apabila aktivitas nyanyi dilakukan dalam bentuk permainan atau nada dan gerak, sehingga mempermudah anak untuk selalu mengingatnya. Apabila orang tua atau guru memiliki kemampuan arransemen lagu maka ciptakanlah lagu, apabila tidak 
mampu cukup membuat gubahan lirik lagu dari lagu-lagu yang familiar di telinga anak.

\author{
Allah Maha Esa \\ Irama : Lagu Burung Kakak Tua
}

Allah Maha Esa, Allah Maha Kaya

Allah Maha Sayang, Allah Maha Tahu

Allah, Allah, Allahu Akbar

Allah, Allah, Allahu Rahman

Allah, Allah, Allahu Rahim

Allah Maha Esa

Allah Ada Dimana-Mana

Irama: Lagu Disini Senang, Disana Senang

Di Rumah Allah

Di Mesjid Allah

Di Sekolah Allah

Dimana-mana ada Allah

Di Langit Allah

Di Laut Allah

Di Bumi Allah

Dimana-mana ada Allah

Metode karyawisata (fieldtrip) dapat digunakan untuk mengenalkan kebesaran dan keagungan sang pencipta dengan cara memahami ciptaannya, dapat dilakukan dengan cara mengunjungi suatu tempat yang menyenangkan seperti pantai. Anak diajak untuk bermain dan merenungkan setiap fenomena yang ada mulai dari luas dan dalamnya lautan, tentang binatang yang hidup di laut, ombak, terumbu karang, apa yang harus dan tidak boleh dilakukan manusia di laut, upacara atau kegiatan ritual di pesisir, dan hal lainnya yang membuat anak tertarik untuk dapat diajak bercakap-cakap. (Elfan Fanhas Fatwa Khomaeny, at.al: 2017)

\title{
2. Mengenalkan Pengetahuan tentang Diri dan Asal Usul Manusia
}

Pengenalan diri manusia telah dilakukan oleh semua orang tua sejak anak lahir ke dunia, secara progresif berkembang dari waktu ke waktu, mulai dari mengenal anggota tubuhnya, namanya, kebutuhannya dan hal lain berkaitan dengan diri manusia. Pengenalan tersebut terbatas hanya pada upaya mengidentifikasi diri, sehingga anak dapat mengetahui identitas dirinya, padahal dalam ajaran Islam jauh 


\section{Elfan Fanhas Fatwa Khomaeny}

lebih komplek dan komprehensif bukan semata-mata mengenal identitas diri, tetapi untuk dapat mengetahui kebesaran dan keagungan Tuhannya, sebagaimana firmanNya dalam Q.S. Fussilat (41):53, yang artinya: "Kami akan memperlihatkan kepada mereka tanda-tanda (kekuasaan) Kami, di segala penjuru alam semesta dan pada diri mereka sendiri, hingga jelas bagi mereka bahwa al-Qur’an itu dalah benar. Tiadakah cukup bahwa sesungguhnya Tuhanmu menjadi saksi atas segala sesuatu" (Kementrian Agama RI,2014:482).

Pengenalan diri manusia dan asal usul manusia harus dilakukan dan dimulai sejak anak usia dini, dan secara bertahap level pengetahuannya meningkat seiring dengan perkembangan anak, dari yang terlihat sampai yang tersembunyai, dari yang besar sampai yang kecil, dari yang nampak diluar sampai dengan apa yang ada di dalam tubuh manusia, sehingga anak mengetahui dan memahami bahwa manusia adalah makhluk yang unik dan memiliki kompleksitas sangat tinggi, tujuan akhirnya adalah membangun kesadaran akan kehebatan sang Khalik sebagai penciptanya.

Pemahaman tentang anggota tubuh, anatomi tubuh, fungsi dan cara kerja anggota tubuh manusia telah melahirkan banyak ilmu pengetahuan, seperti : ilmu anatomi, kedokteran dari yang umu sampai pada spesialis, embriologi, fisiologi, biologi, neuorologi, geneologi, mikrobiologi, dan ilmu lainnya, begitu juga pemahaman tentang sikap, prilaku, dan fenomena manusia telah melahirkan ilmu psikologi, sosiologi, antropologi, ekonomi dan ilmu lainnya.

Pemahaman mendalam akan konsep pendidikan pengenalan diri dan asal usul manusia merupakan bantahan tentang dikotomi ilmu, yang sampai hari ini mengkungkung kebanyakan umat Islam. Pada abad pertengahan dimana Islam mencapai kejayaannya, telah melahirkan ilmuwan sekaligus ulama hebat yang tidak hanya menguasai ilmu al-Qur`an, al-Hadits, dan ilmu alat pendukungnya, tetapi mereka juga menguasai ilmu kealaman, seperti : ibnu Sina, al-Khawarizmi, alhayyan, al-battani, al-biruni, ibnu batutah, ibnu rusyd, al-Farabi, ibnu khaldun, alHarrani, ar-Razi, dan lainnya.

Pada konsep ini, anak juga dikenalkan akan asal usul manusia baik secara syariat yaitu dimana anak terlahir dari kedua orang tuanya, dengan gambaran proses yang panjang dan sulit, sehingga memiliki konsekuensi ketaatan, kepatuhan dan hormat kepada kedua orang tuanya. Begitu juga penciptaan manusia secara hakikat yang bersumber dari Sang Khalik, sehingga memiliki konsekuensi ketaatan, 


\section{Elfan Fanhas Fatwa Khomaeny}

kepatuhan, ketudukan dan penyerahan diri kepada Sanf Pencipta, dimana manusia akan senantiasa menjalankan segala perintahnya, dan menjauhi segala larangannya.

Contoh cara mengenalkan diri dan asal usul manusia, diantaranya: dengan metode refleksi, dimana anak diajak kedalam ruangan yang telah tersedia kaca cermin yang besar, kemudian minta anak untuk bercermin melihat gambaran dirinya pada cermin, untuk menarik perhatian anak ajaklah mereka untuk melakukan gerakan-gerakan lucu atau menarik dengan memainkan ekspresi wajah dan atau tubuh, kemudian ajak anak untuk mengenali setiap anggota tubuh yang ada, dilanjutnya dengan pengetahuan akan fungsi anggota tubuh tersebut yang dibarengi dengan praktek menggunakan anggota tubuh sesuai dengan fungsinya, kemudian cobalah bermain peran, dimana anak beraktivitas dengan menggunakan anggota tubuh yang tidak sesuai dengan fungsinya.

Dengan metode fieldtrip, ajaklah anak untuk melakukan pemeriksaan kesehatan (check up) di puskesmas atau klinik, kenalkan kepada anak tentang anggota tubuh, fungsi dan cara kerja tubuh dibantu oleh ahlinya (dokter, perawat) sambil mengamati gambar-gambar yang ada tempat itu, pada kesempatan ini dapat pula mengajarkan tentang konsep sehat dan sakit, profesi kesehatan dan lainnya. Metode film animasi juga dapat dilakukan untuk mengenalkan diri dan proses penciptaan manusia, metode demontrasi tentang cara kerja tubuh manusia, seperti : manusia untuk hidup perlu oksigen untuk bernafas, maka ajaklah anak untuk menutup hidung dan mulut beberapa saat dan tidak menghirup udara, kemudian setelah tidak kuat dan mulai lagi menghirup udara, setelah itu ajan anak bercakap cakap tentang apa yang terjadi dalam demonstrasi yang dilakukannya, dan masih banyak metode yang dapat digunakan orang tua untuk mengenalkan diri dan asal usul manusia, yang paling penting adalah bagaimana orang tua menciptakan suasana yang kondusif dan menarik bagi anak, sehingga rasa ingin tahu anak muncul dan makin membesar.

\section{Mengajarkan Ilmu Pengetahuan sebagai Landasan Argumentasi dalam} Menjalani Kehidupan.

Ilmu pengetahuan dalam ajaran Islam memiliki tempat yang spesial dan istimewa, sehingga menuntut ilmu bagi umat Islam merupakan sebuah kewajiban sejak ditiupkannya ruh sampai kembalinya ruh kepada yang Mahamemiliki ruh. Seorang muslim yang sedang menjalani proses pencarian ilmu pengetahuan, kemudian meninggal dalam proses pencariannya maka ia disetarakan dengan 


\section{Elfan Fanhas Fatwa Khomaeny}

syuhada yang berjuang di jalan Allah (fii Sabilillah), selain itu orang yang memiliki ilmu pengetahuan akan dimudahkan jalannya menuju surga, bahkan orang yang berilmu dan beriman diangkat kemuliaannya dan memiliki kedudukan yang tinggi dihadapan Sang Pencipta dibandingkan dengan makhluk dan manusia lainnya, sebagaimana firmanNya dalam Q.S. al-Mujadalah (58):11, yang artinya :“...Niscaya Allah akan mengangkat (derajat) orang-orang yang beriman diantara kamu dan orang-orang yang diberi ilmu beberapa derajat. Dan Allah Mahateliti terhadap apa yang kamu kerjakan. (Kementrian Agama RI,2014:544)

Persepsi muslim tentang urgensi ilmu pengetahuan bagi kehidupan, telah jauh melenceng dari apa yang diinginkan Sang Pencipta, yaitu menjadi dasar dan argumentasi berucap dan bertindak bagi manusia dalam menjalani kehidupannya dan untuk mengenal Sang Pencipta melalui pemahaman dan penghayatan akan ciptaannya. Sekarang mencari ilmu lebih berorientasi bagaimana dengan ilmu tersebut manusia dapat mencari pekerjaan, harta, kedudukan, dan kemuliaan yang bersifat duniawi belaka, sehingga ketika ada satu ilmu yang dipelajari dan menguntungkannya, ia akan totalitas mempelajari ilmu itu dan mengabaikan ilmuilmu lainnya, seperti seorang dokter hanya mempelajari ilmu kedokteran belaka yang menunjang profesinya saja, tanpa mempelajari ilmu lainnya seperti: sosiologi, antropologi, ilmu al-Quran dan hadits dan ilmu lainnya, atau seorang kyai/ulama yang hanya mempelajari ilmu al-Qur`an, hadits dan ilmu alat pendukungnya, tanpa mempelajari ilmu kealaman yang akan menunjang pemahamannya yang mendalam dan komprehensif.

Berargumentasi adalah berfikir logis dan kritis atas sebuah fenomena berlandaskan dasar yang kuat dan jelas, untuk berargumentasi maka manusia harus memiliki ilmu pengetahuan yang luas dan komprehensif, karena manusia akan bersentuhan dan berinteraksi dengan kehidupan yang komplek. Ketika berinteraksi dalam beribadah, maka manusia harus mengetahui ilmu ibadah yang baik dan benar, ketika berinteraksi dalam kehidupan politik, maka manusia harus memiliki pengetahuan tentang ilmu politik, ketika manusia berinteraksi dalam kehidupan sosial ekonomi, maka manusia harus memiliki pengetahuan tentang sosial ekonomi, dan ilmu pengetahuan yang berkaitan dengan aspek kehidupan manusia lainnya.

Mengenalkan dan mengajarkan ilmu pengetahuan kepada anak hakikatnya membekali anak untuk berargumentasi dalam menjalani kehidupannya, sehingga kemampuan berfikir kritis dan argumentatif (argumentative and critical thinking) 


\section{Elfan Fanhas Fatwa Khomaeny}

adalah hal yang penting diajarkan kepada anak, sehingga anak tidak akan terjebak pada kebodohan, kejumudan dan taklid. Oleh karena itu, materi pembelajaran bagi anak bukanlah tujuan utama dari pembelajaran tersebut, karena materi pembelajaran dapat berubah dan bisa saja ketika anak dewasa materi tersebut sudah tidak cocok diterapkan dalam kehidupannya. Adapun tujuan utamanya adalah melatih kemampuan berfikir logis, kritis, dan argumentatif pada anak.

Contoh untuk melatih kemampuan berfikir logis, kritis dan argumentatif kepada anak banyak cara dan metodenya, diantaranya : dengan metode bercakapcakap, ketika dalam perjalanan mengantar anak berangkat ke sekolah ajaklah anak bercakap-cakap, ketika berada di jalan yang macet maka buatlah pernyatan terbalik dari faka sebenarnya, "kok jalannya sepinya, ya!", anak akan merespon cepat sesuatu yang tidak sesuai dengan konsepnya, dan akan mengkritik pernyataan tersebut dengan memberikan bantahan, "nggak ramai kok, malah macet, ini buktinya ayah nggak bisa jalan!”. Anakpun akan membuat argumentasi untuk menguatkan pernyataannya "ayah lihat donk! ini banyak mobil, motor, orang berlalu lalang, dan jalanan tersendat". Dalam respon anak terhadap penyataan yang salah atau tidak sesuai keadaan sebenarnya, terkandung sebuah kritik atas atas ketidak sesuaian, mencoba berfikir logis untuk membantah, dan membuat argumentasi untuk menguatkan pendapatnya.

Contoh lainnya dikaitkan dengan kemampuan kebahasaan anak, adalah : ketika mengajak anak berkunjung ke kandang sapi, kemudian kita membuat pernyataan "nak lihat banyak ya pi-sa nya!, anak sesaat akan terdiam untuk selanjutnya merespon dan membuat bantahan "itu sapi, ayah!", kemudian mintalah anak untuk melafalkan kata "pi-sa" dengan cepat, "pi-sa-pi-sa-pi-sa-pi" yang akhirnya anak akan melafalkan kata sapi, dan masih banyak cara dan metode lainnya.

\section{Mengenalkan dan Mengajarkan kepada Anak Pengetahuan tentang Hukum Sebab Akibat (Hukum Kausalitas)}

Kehidupan manusia selalu dihadapkan pada pilihan-pilihan dengan konsekuensi yang menyertainya. Kemampuan untuk memilih pilihan yang baik dan tepat bukanlah perkara mudah, terlebih ketika pilihan itu berdampak hukum, manusia dituntut untuk teliti dan hati-hati dengan pilihannya, karena salah memilih akan berakibat hukuman, begitu pilihan yang pula berkaitan dengan hal-hal yang berdampak pada masa depan anak. Pengetahuan tentang hukum sebab akibat 


\section{Elfan Fanhas Fatwa Khomaeny}

(hukum kausalitas) sangatlah penting diajarkan sejak anak usia dini, sebagai bekal pertimbangan dalam memilih ucapan dan tindakannya ketika memasuki fase dewasa, dimana anak telah memiliki beban kewajiban (taklif) dan atau sebagai obyek hukum, dimana ia akan diminta pertanggungjawaban atas apapun yang telah dilakukannya di dunia maupun di akhirat kelak.

Lukmanul Hakim mengajarkan kepada puteranya tentang hukum kausalitas, dalam rangka menanamkan sikap tanggung jawab yang akan dipikul sebagai orang dewasa. Beliau mengajarkan hal tersebut dengan metode perumpamaan yang sangat indah, ia mengibaratkan perbuatan manusia dengan biji sawi (kecil dan hitam), walaupun terletak pada batu hitam yang besar, berada di dalam perut bumi, atau berada jauh di langit, Allah maha mengetahui dan akan memberikan balasanya, kebaikan akan berbalasa kebaikan, dan sebaliknya. Pertimbangan inilah yang menjadikan putera lukman menjadi seorang bijaksana, karena apapun yang diucapkan dan dilakukannya telah melalui proses pemilahan dan pemilihan, dengan petimbangan baik dan buruk, manfaat dan madharat, dan pertimbangan lainnya.

Hukum sebab akibat yang harus diajarkan kepada anak usia dini berkaitan dengan sandaran ilmu pengetahuan, bukan pada kajian filsafat. Anak diberi pelajaran tentang hubungan sebab dan akibat, sehingga anak memiliki pemahaman bahwa setiap tindakan akan mengakibatkan reaksi, sehingga anak memiliki kesadaran bahwa apa yang dilakukannya itu penting. (Elfan Fanhas Fatwa Khomaeny, et.al: 2018). Tanggung jawab adalah salah satu sikap moral anak yang dibangun atas dasar teori kausalitas, dimana anak membuat pertimbangan atas ucapan dan tindakannya, serta memiliki kesadaran tentang akibat dari sebab yang diambil.

Melatih tanggungjawab pada Anak tidak cukup memodelkan prilaku atau menyatakan harapan, tetapi juga perlu bimbingan untuk membangun prilaku baru, dimana anak diajarkan untuk menjadi penanggung jawab utama bagi prilakunya sendiri, sehingga ukuran kesenangan, kebahagiaan, dan penghargaan bagi perilakunya berdasarkan dari dirinya (internal), bukan atas dasar persetujuan atau penghargaan dari orang lain (eksternal), lebih dikenal dengan konsep lokus kontrol (locus of control). Ketika anak diberi tanggung jawab, anak dilatih untuk mengembangkan pengarahan dirinya lebih besar, tanpa tanggung jawab anak menjadi bosan dan prustasi sehingga bermasalah dalam disiplin (Morisson: 2016 ). 


\section{Elfan Fanhas Fatwa Khomaeny}

Menurut Baqir ash Shadr, hukum kausalitas menjadi sandaran ilmu pengetahuan, yaitu : (1). Prinsip Kausalitas yang menyatakan bahwa setiap peristiwa mempunyai sebab, (2). Hukum keniscayaan yang menyatakan bahwa setiap sebab niscaya melahirkan akibat alaminya, dan tidak mungkin terpisah dari sebabnya, (3). Hukum keselarasan antara sebab dan akibat yang mengatakan bahwa setiap himpunan alam secara esensial selaras mesti pula selaras dengan sebab dan akibatnya (Shadr :1991).

Berikut adalah contoh mengajarkan hukum sebab akibat kepada anak terutama bagi anak usia dini, dengan metode demonstrasi atau eksperimen, yaitu:

Hukum bumerang, merupakan nama lain dari hukum sebab akibat, yang bertujuan mengingatkan anak bahwa manusia akan menuai apa yang yang ditanamnya. Di alam ini setiap pikiran, ucapan dan perbuatan akan kembali kepada sumber penyebab hal tersebut. Pada pembelajaran ini guru mempersiapkan bahanbahan, diantaranya : Karet gelang, bumerang, yoyo atau terompet pesta jika ditiup yang bisa menjulur keluar masuk. Ajaklah anak untuk bermain karet gelang, bumerang, yoyo, dan meniup terompet pesta, berikan kesempatan kepada anak untuk mendemonstrasikannya. Mainkan yoyo, dan lemparkan dengan mengucapkan kata-kata positif, maka ketika berbalik ucapkan kembali kata-kata tersebut atau sebaliknya (Jenkins 2010 : 21-22).

Hukum tarik menarik, mengajarkan apabila kita secara sadar mempunyai suatu pikiran disertai suatu perasaan, kita mengirimkan melalui tubuh kita, dan bersamaan dengan dikirimkannya energi melalui tubuh, maka kita pun menarik energi atau getaran sejenis lainnya (Jenkins 2010 : 48-49). Untuk mengajarkan tentang hukum tarik menarik, sedaikanlah bahan-bahan berikut : dua buah magnet dengan daya tarik kuat, nampan yang penuh dengan benda- benda kecil berbahan besi dan non besi, kemudian ajaklah anak untuk bermain menarik benda dari nampan dengan magnet, ajaklah anak untuk berbincang tentang apa yang dilakukannya.

Dunia saya mencerminkan tindakan saya, pada permainan ini ajaklah anak kesebuah tempat yang ada cermin, lakukankan aktivitas di depan cermin, misal : suruh anak anak untuk tersenyum, maka gambaran anak-anak dalam cerminpun dalam keadaan tersenyum, kemudian suruh anak untuk menjulurkan lidah sebagai ekspresi menghina, maka gambaran anak-anak dalam cerminpun dalam keadaan menjulurkan lidah dan diajarkan bahwa setiap tindakan atau ucapan hakikatnya 
kembali kepada yang bersangkutan. Dan masih banyak metode dan cara untuk dapat mengajarkan hukum sebab akibat sehingga anak menjadi anak yang bertanggung jawab kelak.

\section{Melatih dan Membiasakan Sholat}

Kedudukan Sholat bagi seorang muslim ibarat tiang penyangga, apabila tiang tersebut rapuh dan rusak, maka bangunan yang berada di atasnya akan roboh dan hancur. Begitu pentingnya sholat bagi seorang muslim, menjadikan sholat sebagai ukuran keimanan seseorang, karena pembeda antara muslim dengan kafir adalah sholat. Oleh karena itu Rasulullah s.a.w., mengajarkan kepada umatnya, untuk mengenalkan dan mengajarkan sholat kepada anak sejak usia dini, bahkan ketika anak telah mencapai usia sepuluh tahun, tetapi masih enggak untuk melaksanakan sholat maka orang tua harus mencambuknya (mencambuk untuk pengajaran bukan menyakiti). Bahkan di akhirat kelak amalan yang pertama kali akan dihisab adalah sholat.

Melaksanakan dan membiasakan ibadah sholat bukanlah hal mudah, karena sholat harus mengikuti persis sebagaimana yang dilakukan dan dicontohkan Rasulullah s.a.w. dalam sholat minimal mencakup : aspek keterkaitan hati manusia dengan Allah (khusyu), benar bacaannya (tartil), aspek kesesuaian dan ketertiban gerakan sholat (tartib), dan aspek ketenangan dan kenyamanan dalam menjalankannya(tuma 'ninah).

Dalam perintah pelaksanaan Sholat, hakikatnya Allah sedang melatih manusia untuk hidup tenang, damai, bersih, sehat, tertib, dan disiplin. Ketenangan dan kedamaian akan didapatkan ketika manusia dapat membangun hubungan dan terhubung dengan Sang Pencipta, karena ketenangan dan kedamaian merupakan aspek ruhaniah, dimana ruh akan mencapai puncak kedamaian ketika ruh tersebut didekatkan dengan sumber ruh, yaitu Allah S.W.T,. Sholat membiasakan manusia hidup bersih, karena syarat sah sholat adalah wudhu (thaharah) yang baik dan benar, selain itu akan menjadikan manusia sehat, karena setiap gerakan sholat selain memiliki makna ruhaniah juga berdampak pada kesehatan jasadiah, dengan syarat gerakan sholat dilakukan dengan baik dan benar, tertib dan tuma'ninah sesuai dengan tuntunan rasulullah s.a.w,. Orang sholat akan memiliki fisik yang kuat dan sehat, karena fisik motoriknya selalu terlatih dan kebugaran fisiknya selalu dijaga setiap harinya. 
Dalam pelaksanaan sholat selain berisi pesan tentang ibadah, tersirat pesan kepada manusia untuk selalu melatih dan menjaga kebugaran motoriknya, Sholat juga mengajarkan kepada manusia hidup tertib dan disiplin, karena memiliki syarat sah dan rukun sholat yang harus ditunaikan secara penuh dan berurutan secara sistematis, selain itu sholat juga diperintahkan dengan waktu yang telah ditentukan (kitaaban mauqutan), dan yang lebih penting lagi adalah tata cara sholat harus mengikuti persis dengan apa yang dilakukan oleh Rasulullah s.a.w., dan dilakukan secara rutin minimal 17 rakaat dalam sehari semalam.

Melatih sholat pada anak dilakukan secara bertahap dan berkelanjutan sesuai dengan perkembangan anak, diawali dengan mengajak anak dan mnegnalkan sholat dengan cara membiarkan anak untuk memperhatikan orang tuanya melaksanakan sholat, menstimulus rasa ingin tahu anak tentang sholat yang dilakukan orang tua, mengkondisikan anak untuk merasa nyaman dan memiliki keinginan melakukan sholat dengan cara mengikuti gerakan sholat, latihlah anak gerakan wudhu dan sholat yang benar, setelah gerakannya baik dan benar, selanjutnya latihlah bacaan anak, dilanjutkan dengan tahsinul qiraah, apresiasi anak dengan reward atas setiap pencapaiannya, biasakan anak untuk melakukan sholat yang dibarengi dengan keteladanan dari orang tuanya.

\section{Melatih dan Membiasakan Beramar Maruf Nahi Munkar}

Beramar ma`ruf nahi munkar bagi manusia adalah bentuk perwujudan dari fungsi khalifatullah fiil ardi, yang harus menjaga keseimbangan, kedamaian, kesejahteraan, dan melestarikan kehidupan manusia dan alam semesta dalam harmoni ilahi rabbi, sebagaimana firmanNya dalam Q.S. al-Imran (3):110) yang artinya: "kamu adalah umat yang terbaik yang dilahirkan untuk manusia, menyuruh (berbuat) yang ma'ruf, dan mencegah dari yang munkar, dan beriman kepada Allah. Sekiranya Ahli Kitab beriman, tentulah itu lebih baik bagi mereka; diantara mereka ada yang beriman dan kebanyakan mereka adalah orang-orang yang fasik. (Kementrian Agama RI, 2014:64).

Kemampuan seseorang untuk mengajak kepada yang maruf dan mencegah yang munkar tidak akan muncul dengan sendirinya, tetapi melalui sebuah proses pelatihan dan pembiasaan yang dilakukan dalam keluarga. Kemampuan tersebut meliputi kemampuan menyampaikan kebenaran dan mencegah kemunkaran dengan lisan, tangan atau kebijakan, serta do`a yang dapat membuat perubahan, serta mempersiapkan mental dalam melakukannya. Seseorang yang akan beramar ma`ruf 


\section{Elfan Fanhas Fatwa Khomaeny}

nahi munkar selain memiliki ilmu dan wawasan yang luas, kemampuan berfikir logis dan kritis, kemampuan berkomunikasi, juga haruslah memiliki fisik yang kuat dan sehat, sehingga melatih dan memastikan anak-anak memiliki fisik yang kuat dan sehat adalah perintah dalam ajaran Islam, sebagaimana anjuran Nabi yang memerintahkan kepada umat Islam untuk mengajarkan anak-anaknya memanah, berkuda, dan berenang, yang merupakan simbolik, bahkan dalam sabda lainnya seorang mukmin yang kuat lebih dicintai dibandingkan dengan mukmin yang lemah.

Melatih dan membiasakan amar ma`ruf nahi munkar pada anak dapat dilakukan dengan cara melatih fisik motorik anak, kemampaun kebahasaan anak, kemampuan berfikir logis dan kritis, dan kemampuan berkomunikasi dengan menggunakan metode yang tepat disesuaikan dengan materi yang akan disampaikan.

\section{Melatih dan Membiasakan Anak untuk Bersabar}

Point 7 sampai point 11 dalam konsep pendidikan Lukmanul Hakim yaitu pendidikan keluarga berkaitan dengan penanaman dan pengembangan karakter anak, yang harus dimulai dan dilakukan sejak anak usia dini secara berkesinambungan. Mendidik karakter anak ibarat menanam pohon buah, apabila dilakukan dengan baik dan tepat, sungguh-sungguh, telaten, berkesinambungan dengan adanya pembiasaan dan keteladanan dari orang-orang sekitarnya, mampu menjaga dari serangan hama atau pengaruh buruk dari luar, maka ketika waktu berbuah telah tiba akan menghasilkan buah terbaik. Karakter yang harus dilatihkan dan dibiasakan kepada anak adalah sikap sabar, yaitu suatu sikap tahan menghadapi cobaan, tidak lekas putus asa, tidak lekas patah hati, tidak lekas marah, tenang, tidak tergesa-gesa, dan tidak terburu nafsu.

Sabar bukanlah sikap karakter anak hanya dapat dipelajari secara teoritis, tetapi harus dipraktekkan dan dibiasakan. Sikap sabar haruslah disandingkan dengan sikap kesungguhan (mujahadah) dan tawakkal, sehingga sabar tidak salah makna menjadi pasrah tanpa ada usaha (fatalism), atau menjadi pecundang, karena sabar adalah menyelesaikan pekerjaan secara optimal dalam penggunaan waktu dan energi, adapun hasil usaha diserahkan kepada Sang pencipta. Orang yang sabar walaupun dia menunggu, tetapi selalu menghasilkan karya.

Orang tua harus melatih dan membiasakan karakter sabar kepada anak, karena sabar merupakan kunci kesuksesan bagi anak di masa depannya. Melatih kesabaran kepada anak hakikatnya adalah membekali anak untuk hidup sukses karena Allah bersamanya, sebagaimana firmanNya dalam Q.S. Al-Baqarah (2):153, yang artinya: 
"Wahai orang-orang yang beriman jadikanlah sholat dan sabar sebagai penolongmu. Sesungguhnya Allah bersama orang-orang yang sabar. (Kementrian Agama RI, 2014:23).

Contoh melatih kesabaran dengan metode proyek, anak diberi tugas-tugas dan proyek oleh orang tua, mintalah anak untuk menyelesaikan tugas dan proyeknya sesuai dengan instruksi, ketika anak mengalami kesulitan beri motivasi dan semangat untuk menyelesaiakan tugasnya, dengan memberikan masukan alternatif cara menyelesaikan tugas bukan membantunya, yakinkan anak bahwa tidak ada tugas yang tidak dapat diselesaikan apabila anak mau berusaha sungguh-sungguh, karena usaha yang optimal adalah keberhasilan itu sendiri. Orang tua juga dapat melatih kesabaran anak untuk memenuhi keinginan untuk membeli atau memiliki suatu barang dengan cara token ekonomi, dimana anak baru dapat membeli atau memiliki sesuatu yang diinginkannya apabila telah mencapai jumlah bintang tertentu, dan bintang tersebut didapatkan dari orang tua karena anak menyelesaikan tugas-tugas dari orang tuanya.

\section{Melatih dan Membiasakan Anak untuk Memiliki Kepedulian kepada Sesama}

Manusia selain makhluk individu, juga sebagai makhluk sosial yang tidak dapat hidup sendirian dan terisolir, serta membutuhkan bantuan dan pertolongan sesamanya. Teori interkasi sosial "take and give" memiliki makna bahwa manusia akan menerima sesuatu dari sesamanya, apabila orang tersebut memberikan sesuatu kepada sesamanya atau timbal balik, di sisi lainnya bahwa kehidupan manusia itu ibarat roda kadang berada pada posisi di atas, kadang pula berada pada posisi di bawah, hari ini manusia membantu, suatu saat menjadi orang yang dibantu, hari ini menjadi orang yang diminta pertolongan, suatu saat menjadi orang yang meminta pertolongan.

Sifat dasar manusia, ketika berada pada posisi di atas seringkali lupa bahwa suatu saat kondisi dapat berubah sebaliknya, sehingga menjadikan dirinya angkuh dan tidak mau peduli kepada sesamanya, merasa diri dapat melakukan apapun tanpa adanya bantuan orang lain. Ketika seseorang berada pada posisi di bawah dan memerlukan uluran bantuan dari sesamanya, baru memiliki kesadaran akan pentingnya kepedulian kepada sesama dan menyesal.

Sifat peduli yang berwujud simpati atau yang lebih dalam adalah empati, haruslah menjadi karaktek yang menonjol pada diri anak, dan sikap ini tidak akan muncul dengan sendirinya, tetapi harus dilatih, dibiasakan, dan diberi contoh oleh 


\section{Elfan Fanhas Fatwa Khomaeny}

keluarga. Untuk melatih sikap simpati dan empati kepada anak, orang tua harus mendorong anaknya berinteraksi dan bermain dengan berbagai macam latar belakang anak yang berbeda, baik sosial, ekonomi, agama, budaya, ras, dan warna kulit, latihlah anak untuk memahami perbedaan dan menerima perbedaan tersebut, saling menghormati dan menghargai, dan saling tolong menolong.

Contoh cara melatih simpati dan empati dengan metode fieldtrip, ajaklah anak ke tempat-tempat dimana orang yang kurang beruntung tinggal, seperti: panti asuhan, rumah jompo, rumah kardus, rumah singgah, dan lainnya, biarkan anak mengamati dan berinteraksi langsung, latih dan biasakan anak untuk berbagi dari apa yang dimilikinya, kemudian ajak anak bercakap-cakap tentang pengalamannya, dan sentuh hati anak dengan aktivitas refleksi diri.

\section{Melatih dan Membiasakan Anak untuk Tidak Memiliki Sifat Sombong dan Angkuh.}

Sikap sombong adalah menghargai diri secara berlebihan, congkak, dan pongah sebagai dasar dari setiap keburukan, kemaksiatan dan kemunkaran manusia. Sombong merupakan salah satu karakter dari orang kafir yang menutup diri dari kebenaran ilahi, sebagaimana firmanNya Q.S Al-Baqarah (2):34, yang artinya: "Dan (ingatlah) ketika Kami berfirman kepad para malaikat, "Sujudlah kamu kepada Adam!", maka mereka pun sujud kecuali Iblis, ia menolak dan menyombongkan diri, dan ia termasuk golongan yang kafir. (Kementrian Agama RI, 2014:6). Inilah yang menjadikan Iblis terusir dan terkutuk oleh Allah (Q.S. Al Hijr (15):34) begitu pula pengikut iblis seperti Fir`au, Qorun, Haman, Namrudz dan yang lainnya celaka dan akan disiksa oleh Allah karena kesombongan diri.

Melatih anak untuk rendah hati dan tidak sombong harus diusahakan, sebagai upaya orang tua untuk membekali dan menyelamatkan anak dari kemurkaan Allah dan supaya dapat diterima keberadaannya di tengah-tengah masyarakat, karena orang sombong tidak disukai khalik dan makhluk. untuk melatih sikap rendah hati dapat menggunakan metode akuisisi yang akan membangun kesadaran bahwa apa yang ada pada dirinya dan atau semua yang ada di dunia bersifat fana, cepat atau lambat semua akan rusak dan menghilang. Metode lain yang dapat digunakan adalah metode bercerita tentang kisah orang-orang sombong dan akibat yang timbul disebabkan kesombongannya, atau menggunakan metode tanyangan film animasi yang mengangkat tema kesombongan dan akibatnya bagi manusia, dan masih banyak metode lainnya. 


\section{Melatih dan Membiasakan Anak untuk Hidup Bersahaja}

Melatih dan membiasakan anak untuk hidup bersahaja, bukan berarti menjadikan anak miskin atau melarat, dan tidak membolehkan memiliki harta kekayaan yang melimpah, karena hidup bersahaja adalah hidup sederhana dan tidak berlebihan, dengan memiliki ketaatan kepada Allah dan hidup pada jalan lurus yang diridhai Allah, Jujur, adil dan menjadi umat pertengahan yang tidak berlebihan, sebagaimana firmanNya dalam Q.S. Al-Araf (7):31, yang artinya: "Wahai anak cucu Adam! Pakailah pakaianmu yang bagus pada setiap (memasuki) mesjid, makan dan minumlah, tetapi jangan berlebihan. Sungguh, Allah tidak menyukai orang-orang yang berlebihan. (Kementrian Agama RI, 2014:154).

Sikap bersahaja inilah yang harus dilatihkan dan dibiasakan kepada anak, karena hidup bersahaja merupakan salah satu prinsip dasar ajaran Islam, sebagaimana keteladanan pada diri rasulullah s.a.w, faktanya beliau adalah seorang pengusaha sukses yang memiliki harta berlimpah, terlebih istrinya Khadijah r.a. adalah sosok pengusaha sukses yang memiliki kekayaan harta berlimpah. Melimpahnya harta kekayaan tidak menjadikannya hidup mewah dan bermegahmegahan, tetapi beliau menempuh jalan sederhana dan bersahaja yang hidup sesuai dengan kebutuhan bukan keinginan. Adapun kelebihan harta yang dimilikinya dihabiskan untuk membantu sesama dan memperjuangkan agama Islam.

Melatih hidup bersahaja kepada anak dengan cara memenuhi kebutuhan anak sesuai dengan kebutuhannya, mengendalikan pemenuhan keinginan anak, membeli barang sesuai dengan manfaat dan kegunaannya bukan karena gengsi, latih untuk menjaga dan merawat barang yang dimilikinya, latih menghargai makanan dan minuman dengan tidak berprilaku mubadzir.

\section{Melatih dan Membiasakan Anak untuk Memiliki Sopan Santun.}

Risalah kenabian yang diemban oleh Rasulullah s.a.w., selain untuk mengajarkan ajaran tauhidullah, juga untuk memperbaiki dan menyempurnakan akhlak manusia. Ajaran Islam selain diajarkan kepada umatnya, juga tercermin dan terejawantahkan dalam sikap dan perilaku nabi Muhammad s.a.w, sebagaimana diungkapkan istrinya Aisyah r.a, yang menyatakan bahwa akhlak Rasulullah adalah al-Qur`an.

Sikap sopan dan santun dalam ajaran Islam menjadi salah satu ciri dan karakteristik ajarannya, hal ini dapat ditemukan dan tersirat dalam banyak ayat al- 


\section{Elfan Fanhas Fatwa Khomaeny}

Qur`an yang mengatur hubungan manusia dengan Allah, manusia dengan sesamanya, serta manusia dengan alam semesta. Sikap sopan santun manusia kepada Allah, seperti : menghadapNya dalam keadaan suci, berdoa dengan penuh pengharapan dan suara lemah lembut, berdoa dengan nama-nama baik Allah (asmaul husna), prasangka baik (husnudzan) dan lainnya. Sopan santun kepada manusia, seperti : bertutur kata yang baik, tidak menghina, tidak menyakiti, bahkan volume suara saja harus diatur, lemah lembut dan kasih sayang, saling menghargai dan menghormati, dan lainnya, begitu juga kepada alam semesta, seperti : tidak merusak alam, tidak menyembelih hewan dengan dzalim, tidak membuang air kecil sembarangan, dan lainnya.

Sikap sopan dan santun pada anak harus dilatihkan dan dibiasakan sejak anak usia dini, dengan adanya keteladanan dari orang orang terdekat yang ada di sekitarnya. Sebagai contoh melatih anak untuk bertutur kata yang baik dan mengatur volume suara ketika berbicara dengan orang yang lebih tua, mau mendengarkan dan menghormati orang yang berbicara, selalu mengucapkan salam ketika bertemu dengan sesamanya, hormat dan taat kepada orang tua dan guru, dan lainnya.

\section{SIMPULAN}

Konsep pendidikan Lukmanul Hakim dalam keluarga berdasarkan pemahaman terhadap Q.S. Lukman (31):12-19, adalah sebagai berikut: (1) Mengenalkan pengetahuan tentang sang pencipta; (2) Mengenalkan pengetahuan tentang diri dan asal usul manusia; (3) Mengajarkan ilmu pengetahuan sebagai landasan argumentasi dalam menjalani kehidupan; (4) Mengenalkan dan mengajarkan kepada anak pengetahuan tentang hukum sebab akibat (hukum kausalitas); (5) Melatih dan membiasakan sholat; (6) Melatih dan membiasakan beramar maruf nahi munkar; (7) Melatih dan membiasakan anak untuk bersabar; (8) Melatih dan membiasakan anak untuk memiliki kepedulian kepada sesama; (9) Melatih dan membiasakan anak untuk tidak memiliki sifat sombong dan angkuh; (10) Melatih dan membiasakan anak untuk hidup bersahaja; (11) Melatih dan membiasakan anak untuk memiliki sopan santun.

Konsep pendidikan tersebut dapat diterapkan oleh orang tua dalam mendidik anak dengan berbagai macam metode dan model disesuaikan dengan materi yang akan disampaikan, Metode pendidikan dan pembelajaran yang dapat digunakan oleh orang tua dalam mengasuh dan mendidik anaknya, diantaranya adalah : 
metode perumpamaan, metode klasikal atau nasihat, pembiasaan, perintah dan larangan, penghargaan (targhib) dan hukuman (tarhib), metode berkisah/ bercerita, metode bercakap-cakap atau dialog, metode keteladanan, metode demonstrasi dan eksperiment, metode kelompok, metode akuisisi, dan masih banyak metode lainnya yang dapat digali dan dikembangkan. Adapun metode yang paling utama dan harus selalu ada dalam pendidikan keluarga adalah metode pembiasaan dan keteladanan.

\section{DAFTAR PUSTAKA}

Abdullah Katutu, Abur Hamdi Usman. (2015). Lukman Al-Hakim Messages: A Theoretical Model on How to Teach In Modern Era. Mediterranean Journal of Social Sciences, Vol 6 No 6 S4 December 2015, ISSN 2039-2117 (online) ISSN 2039-9340 (print). Page. 175-180.

Abi al-Husaini Muslim bin al-Hujaj al-Qasyiri al-Nasaburi (1998). Shahih Muslim. Beirut: Dar al-Kutub al-'Ilmiyah.

Baqir Ash Shadr. (1991). Falsafatuna. (penerjemah Muhammad Nur Mufid). Bandung : Mizan

Chandrawaty dan Elfan Fanhas Fatwa Khomaeny (2019). TK Aisyiyah Bustanul Athfal :Dulu, Kini, dan Esok (Refleksi Kiprah Satu Abad TK ABA dalam membangun negeri). Tasikmalaya : Edu Publisher. Available e-book at : https://books.google.co.id/books?id=TKKoDwAAQBAJ\&printsec=frontcover\&d $\mathrm{q}=\mathrm{TK}+$ aisyiyah\&hl=id\&sa=X\&ved=0ahUKEwj-

1aCajaLmAhUBVysKHcj5CUoQ6AEIKDAA\#v=onepage \&q=TK\%20aisyiyah \&f=fal se.

Elfan Fanhas Fatwa Khomaeny, Iyan Sofyan, dan Fajar Nugraha. (2018). Introducing the Law of Causality to The Early Childhood. Proceeding of International Conference On Child-Friendly Education, Universitas Muhammadiyah Surakarta, April 21st22nd, 2018 ISSN: 2503-5185, p. 454-461. Available at: https://publikasiilmiah.ums.ac.id/handle/11617/10027

Elfan Fanhas Fatwa Khomaeny, Nandhini Hudha Anggarasari. (2017). Introducing The Creator To The Early Childhood. Proceeding The 1st International Conference on Education. Universitas Pendidikan Indonesia Kampus Tasikmalaya, December 21-22, 2017

Elfan Fanhas Fatwa Khomaeny, Nur Hamzah (2019). Metode-Metode Pembelajaran Pendidikan Karakter Untuk Anak Usia Dini Berdasarkan Q.S. Lukman (31):12-19. Tasikmalaya: Edu Publisher. Available e-book at https://books.google.co.id/books?id=tELADwAAQBAJ\&printsec=frontcover\&dq =metode+pembelajaran+pendidikan+karakter \&hl=id\&sa=X\&ved=0ahUKEwjVw s68jKLmAhUVWX0KHU0cB2AQ6AEILzAB\#v=onepage $\& \mathrm{q}=$ metode $\% 20$ pembelaj aran\%20pendidikan\%20karakter\&f=false

Elfan Fanhas Fatwa Khomaeny. (2017). "The Concept of Family Education According to Q.S Lukman: 13-19". Proceedings of the ICECRS, Volume 1 No 2 (2017) 1-6 ISSN. 
2548-6160 ICIGR 2017, 24-25 November 2017, Universitas Muhammadiyah Sidoarjo, Indonesia.Available online: http://ojs.umsida.ac.id/index.php/icecrs Article DOI: https://doi.org/10.21070/picecrs.v1i2.1427.

George S Morrison (2016). Pendidikan Anak Usia Dini Saat Ini Edisi 13 (penerj Yudi Santoso). Yogyakarta : Pustaka Pelajar.

Jenny S Radesky, Sarah E Domoff. (2019). "Mobile Media and parenting. Pp. 1-6 The International Encyclopedia of Media Literacy. John Wiley \& Sons, Inc. DOI: 10.1002/9781118978238.ieml0167.

Kathleen I. Harris. (2014). Embracing Make-Believe Play and Theories of Childhood: Understanding Children's Spirituality and the Spiritual Essence of a Young Child. International Journal of Integrative Pediatrics and Environmental Medicine, p. 12-21.

Kementrian Agama RI. (2014) Al-Quran, Tajwid, dan Terjamahnya. Solo : Penerbit Abyan. Klaus Schwab, 2018. Insight Report The Global Competitiveness Report 2018. World Economic Forum. The Report and an interactive data platform are available at www.weforum.org/gcr.

Latifatul Masruroh. (2015). Metode Pendidikan dalam al-Qur'an (Kajian Surat Luqman Ayat 12-19)". Jurnal Risaalah, Vol . 1 , No. 1, Desember 2015. Hal. 43-52.

Maia Cucchiara. (2013). "Are We Doing Damage?" Choosing an Urban Public School in an Era of Parental Anxiety. Anthropology \& Education Quarterly, Vol. 44, Issue 1, pp. 75-93, ISSN 0161-7761, online ISSN 1548-1492. DOI:10.1111/aeq.12004.

Margaret Nelson (2010) Parenting Out of Control: Anxious Parents in Uncertain Times. New York: New YorkUniversity Press.

Peggy Joy Jenkins. (2010). Simple Hands-On Activities: Nurturing Spirituality in Children. (Penerjemah Lina Jusuf). Jakarta: Gramedia Pustaka Utama.

Puji Asmaul Chusna. (2018). Konsep Dasar Pendidikan Anak Selayang Pandang Lukman al-Hakim. Jurnal al-Makrifat Vol 3, No 1, April 2018. Hal 155-167.

Purwatiningsih, Fachrur Razi Amir, Muhammad Khoiruddin. (2016). Pendidikan Anak dalam Keluarga menurut al-Qur'an Kajian Surah al-Luqman Ayat 13-18. Jurnal Ta'dibi ISSN 2442-4994 Volume 5 Nomor 2, Oktober 2016 Hal 90-97.

Subhan. (2018). Konsep Pendidikan Anak Menurut Al-Qur'an Surat Lukman Ayat 13-19. Jurnal Pendidikan IPS, Vol. 8. No. 1, Januari-Juni 2018 ISSN: 2088-0308. Hal 8593. 